\title{
CHARACTERIZATION OF AG:ZNO THIN FILMS AND THEIR USE IN PHOTOELECTROCATALYTIC DEGRADATION OF METHYLENE BLUE (MB)
}

\author{
Bhishma Karki, Jeevan Jyoti Nakarmi, Rhiddi Bir Singh \\ and Manish Banerjee
}

Journal of Institute of Science and Technology

Volume 22, Issue 2, January 2018

ISSN: 2469-9062 (print), 2467-9240 (e)

Editors:

Prof. Dr. Kumar Sapkota

Prof. Dr. Armila Rajbhandari

Assoc. Prof. Dr. Gopi Chandra Kaphle Mrs. Reshma Tuladhar

JIST, 22 (2): 109-116 (2018)

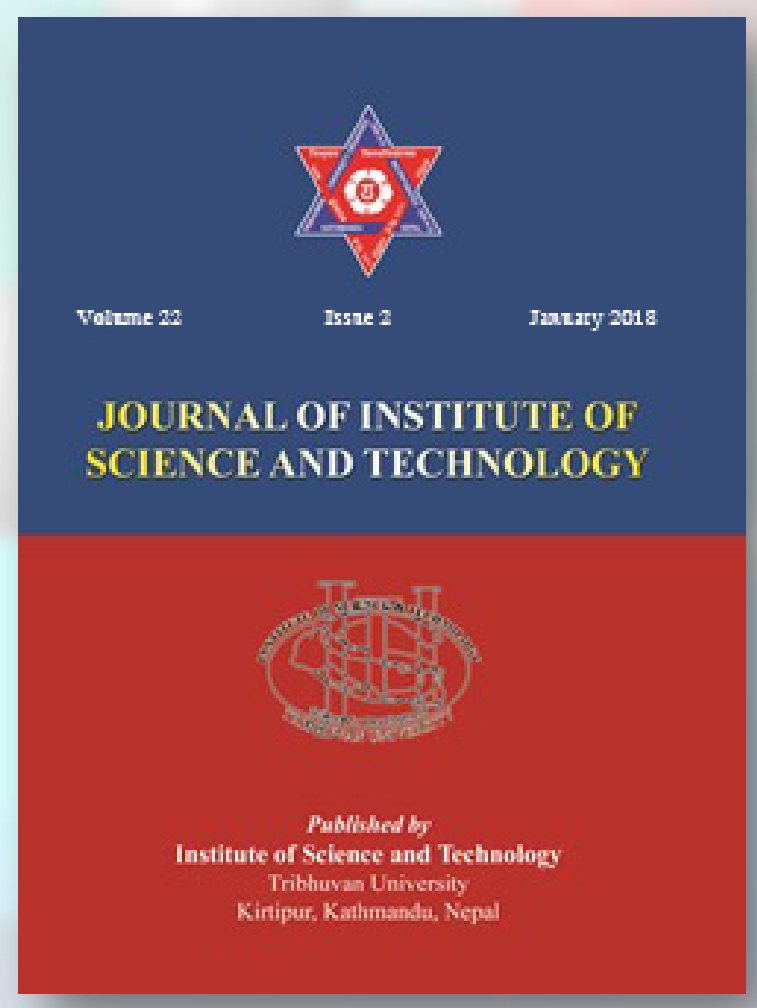

Published by:

Institute of Science and Technology

Tribhuvan University

Kirtipur, Kathmandu, Nepal 


\title{
CHARACTERIZATION OF AG:ZNO THIN FILMS AND THEIR USE IN PHOTOELECTROCATALYTIC DEGRADATION OF METHYLENE BLUE (MB)
}

\author{
Bhishma Karki $^{{ }^{*}}$, Jeevan Jyoti Nakarmi ${ }^{1}$, Rhiddi Bir Singh ${ }^{2}$, Manish Banerjee ${ }^{3}$ \\ ${ }^{1}$ Central Department of Physics, Tribhuvan University, Kirtipur, Kathmandu, Nepal \\ ${ }^{2}$ Central Department of Chemistry, Tribhuvan University, Kirtipur, Kathmandu, Nepal \\ ${ }^{3}$ Department of Chemistry, National Institute of Technology, Patna, Patna-800005, Bihar, India \\ *Corresponding E-mail: magnum.photon@gmail.com
}

Received: 28 July, 2017; Revised: 25 December, 2017; Accepted: 26 December, 2017

\begin{abstract}
The synthesis of functional nano-particles via spray pyrolysis technique (SPT), especially those of catalytic nature, has attracted the interests of scientists and engineers, as well as industries. The rapid and high temperature continuous synthesis yields nano-particles with intrinsic features of active catalysts, that is, high surface area and surface energetic. For these reasons, SPT finds applications in various thermally inducible catalytic reactions. However, the design and synthesis of photocatalysts by SPT requires a knowledge set which is different from that established for thermal catalysts. Unknown to many, this has resulted in frustrations to those entering the field unprepared, especially since SPT appears to be an elegant tool in synthesizing oxide nano-particles of any elemental construct. From simple oxide to doped-oxide, and mixed metal oxide to the in situ deposition of noble metals, this Perspective gives an overview on the development of photocatalysts made by SPT in the last decade that led to a better understanding of the design criteria. Various challenges and opportunities are also highlighted; especially those beyond simple metal oxides, which perhaps contain the greatest potential for the exploitation of photocatalysts design by SPT.
\end{abstract}

Keywords: Nano-particles, SPT, Photoelectrocatalytic processes, Electron-hole pair, SPR.

\section{INTRODUCTION}

$\mathrm{ZnO}$ has been extensively investigated as one of the potential semiconductor photocatalyst used in water purification. However, a major limitation to achieve high photocatalytic efficiency in semiconductor nanoparticle systems is the quick recombination rate of photo-induced charge carriers (Karunakaran et al., 2010). To overcome this limitation, one efficient way is to dope noble metals, such as gold, platinum (Li et al., 2012) and silver in the $\mathrm{ZnO}$ semiconductors. On the other hand, strong antibacterial activities of both $\mathrm{Ag}$ and $\mathrm{Ag}^{+}$have been known for a long time (Cho et al., 2011; Khomchenko et al., 2010). $\mathrm{ZnO}$ is inorganic antibacterial agent, it can be expected that $\mathrm{ZnO}$ will be an excellent support for $\mathrm{Ag}$ atoms. In addition, these $\mathrm{Ag}: \mathrm{ZnO}$ may inhibit the growth of bacteria synergistically due to the strong interaction between them. Keeping these views in mind, we planned to dope silver and gold in $\mathrm{ZnO}$ matrix, which not only inhibit photo-corrosion of $\mathrm{ZnO}$ electrode but also enhance the degradation of methylene blue (MB) and inactivation rate of the bacteria.

This research deals synthesis and characterization of $\mathrm{Ag}$ doped $\mathrm{ZnO}$ thin films. Influence of doping concentration onto PEC structural morphological, optical and luminescence properties has been investigated. Moreover large area $\left(100 \mathrm{~cm}^{2}\right) \mathrm{Ag}$ doped $\mathrm{ZnO}$ thin films have been prepared on FTO coated glasses $(10-15 \Omega)$.

\section{MATERIALS AND METHOD}

The corning glasses and conducting FTO were used as substrates for $\mathrm{Ag}: \mathrm{ZnO}$ thin film deposition by spray pyrolysis technique. In thin film deposition process, substrate cleaning is an important factor to get reproducible films as it affects the smoothness, uniformity, adherence and porosity of the films. The substrate cleaning process depends upon the nature of the substrate; degree of cleanliness 
required and nature of contaminates to be removed. The common contaminates are grease, adsorbed water, air borne dust, lint, oil particles etc. The corning glasses of dimensions $0.125 \mathrm{~cm} \times 7.5 \mathrm{~cm} \times$ $2.2 \mathrm{~cm}$ and $0.125 \mathrm{~cm} \times 10 \mathrm{~cm} \times 10 \mathrm{~cm}$ have been used as substrates. The following process has been adopted for cleaning the substrates.

1. The substrates were washed with detergent solution 'Labolene' and then with water.

2. These substrates were boiled in $0.1 \mathrm{M}$ chromic acid for about five minutes.

3. Substrates were cleaned with distilled water.

4. These substrates were kept in $\mathrm{NaOH}$ solution to remove the acidic contaminations.

5. The substrates were again washed with distilled water and cleaned ultrasonically.

6. Finally, the substrates were dried in alcohol (methanol) vapors.

Thereafter, fluorine doped tin oxide (FTO) conducting coatings were prepared onto the corning glass substrates. Initial ingredients (i) Pentahydrated stannic chloride ( $\mathrm{SnCl} 4 \cdot 5 \mathrm{H} 2 \mathrm{O})$ (purity $99 \%$ ), (ii) Ammonium fluoride (NH4F) (99\%), (iii) Oxalic acid $((\mathrm{COOH}) 2 \times 2 \mathrm{H} 2 \mathrm{O})(99 \%)$ and (iv) Propane-2-ol (Iso-propyl alcohol) (CH3CHOHCH3) (99\%) used to deposit FTO thin films were procured from SD Fine Chem. Mumbai.

A total of $50 \mathrm{ml}$ of $2 \mathrm{M}$ stannic chloride $(35.7 \mathrm{gm}$ ) solution was prepared in doubled distilled water and $7.14 \mathrm{gm}$ of ammonium fluoride was dissolved in it. A few drops of oxalic acid were added to it to clear off some of the precipitated traces. From the above mixture, $10 \mathrm{ml}$ solution was taken and $10 \mathrm{ml}$ of propane-2-ol was added to it to have a total of 20 $\mathrm{ml}$ spraying solution.

The final solution was sprayed onto the corning glass substrates of size $0.125 \mathrm{~cm} \times 2.5 \mathrm{~cm} \times 7 \mathrm{~cm}$ through the specially designed glass nozzle. The compressed $\left(2.5 \mathrm{~kg} \mathrm{~cm}^{-}{ }^{2}\right)$ air was used as carrier gas at a constant spray rate of $4.5 \mathrm{ml} \mathrm{min}{ }^{-1}$. The substrate temperature was maintained at $475{ }^{0} \mathrm{C}$. The conducting films thus prepared have sheet resistivity of the order of 5-15 $\Omega-\mathrm{m}$ and with transparency of 90-95\%. After optimizing all these deposition conditions, FTO films were coated on large area corning glass substrates of size $0.125 \mathrm{~cm}$ $\times 10 \mathrm{~cm} \times 10 \mathrm{~cm}$. These large areas FTO substrates were uniform with resistivity of 5-15 $\Omega-\mathrm{m}$ at the centre and around 20-30 $\Omega-\mathrm{m}$ as we go towards its edges. Prior to using FTO as substrates for $\mathrm{Ag}: \mathrm{ZnO}$ deposition, they were first etched in $\mathrm{HCl}$ and finally cleaned with acetone.
$\mathrm{Ag}: \mathrm{ZnO}$ thin films were deposited onto corning glass and FTO by spray pyrolysis technique. Initial ingredients (procured from Thomas Baker Chem. Mumbai) used to deposit $\mathrm{Ag}: \mathrm{ZnO}$ thin films were (i) Zinc Acetate $(\mathrm{Zn}(\mathrm{CH} 3 \mathrm{COO}) 22 \mathrm{H} 2 \mathrm{O}$, Molecular weight $\left.=219.18 \mathrm{~g} \mathrm{~mol}^{-1}\right)($ AR grade, $99.9 \%$ pure $)$, (ii) Methanol $(\mathrm{CH} 3 \mathrm{OH})(99.9 \%)$, (iii) Acetic Acid (99\%), and (iv) Silver Nitrate $\left(\mathrm{AgNO}_{3}\right),(99 \%)$.

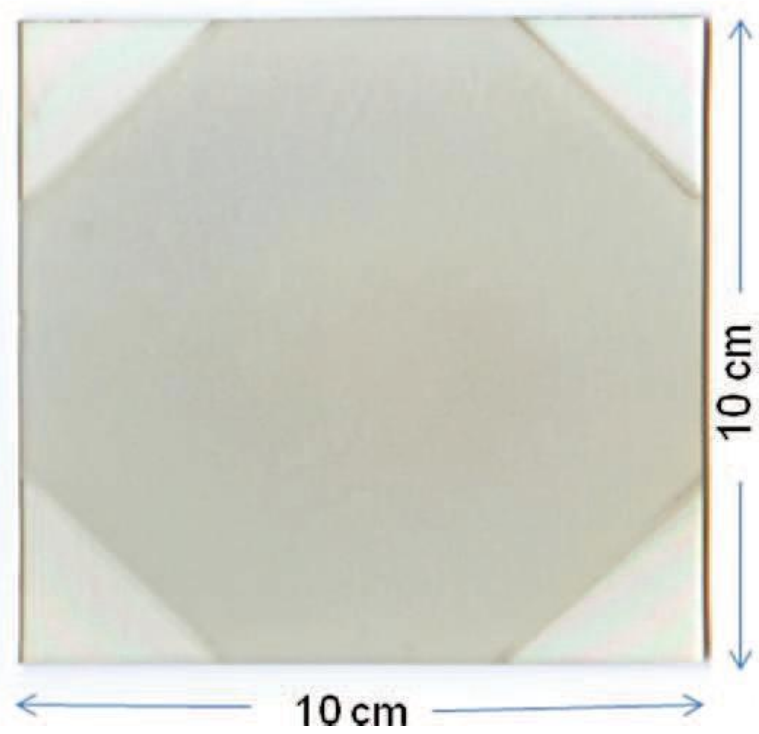

Fig. 1. ZnO thin film on FTO coated glass.

Pure and $\mathrm{Ag}: \mathrm{ZnO}$ thin films have been deposited onto the ultrasonically cleaned glass substrates using zinc acetate as a precursor solution with the SPT. For growth of pure $\mathrm{ZnO}$ thin films, zinc acetate solution was used, while for growth of Ag: $\mathrm{ZnO}$ thin film, silver nitrate and zinc acetate precursors were used. An appropriate quantity of silver nitrate $(0.2 \mathrm{M})$ solution was mixed into the zinc acetate solution to accomplish different doping concentrations (i.e. 1, 2, 3 and 4 At \%) and subsequently the initial and deposited samples are denoted by $\mathrm{ZnO}$ pure, $\mathrm{ZnOAg}_{1}, \mathrm{ZnOAg}_{2}, \mathrm{ZnOAg}_{3}$, $\mathrm{ZnOAg}_{4}$ respectively. The resulting solution was then pulverized pneumatically by means of a specially designed glass nozzle on to the preheated substrates. The sprayed droplets undergo evaporation, solute condensation and thermal decomposition, thereby resulting in the formation of $\mathrm{ZnO}$ thin films. During the synthesis, various preparative parameters like solution quantity (100 $\mathrm{ml})$, solution spray rate $(5 \mathrm{ml} / \mathrm{min})$, nozzle to substrate distance $(30 \mathrm{~cm})$, carrier gas flow rate $(2.5$ $\mathrm{kg} \mathrm{cm}^{-1}$ ) etc. were kept at their optimized values. The deposition temperature was kept constant at $400{ }^{\circ} \mathrm{C}$ for the deposition of all samples. 


\section{RESULTS AND DISCUSSION}

\section{Structural analysis}

The X-ray diffraction patterns $\left(\mathrm{C}_{\mathrm{r}} \mathrm{K} \alpha\right.$ ", $\lambda=2.2897$ $\AA$ ) of undoped and silver doped $\mathrm{ZnO}$ thin films are shown in Figure 2. The spectrum of undoped $\mathrm{ZnO}$ thin film shows typical X-ray diffraction pattern of has hexagonal crystal structure (JCPDS No. 800074). Ag can be incorporated in $\mathrm{ZnO}$ system either by substitution of $\mathrm{Zn}^{2+}$ or by interstitial atom (Lee et al., 2011; Karunakaran et al., 2011; Jin et al., 2011; Xiang et al., 2010). If the silver is substituted for $\mathrm{Zn}^{2+}$, a corresponding peak shift would be expected in XRD. Simultaneously, compared to the (002) diffraction peak of typical undoped $\mathrm{ZnO}$ film which located at $2 \theta=52.13^{\circ}$, the (002) and that of 1 At $\%$ to 4 At $\%$ located at, $2 \theta=52.15^{\circ}, 52.17^{\circ}$, $52.18^{\circ}$ and $52.23^{\circ}$ respectively. Khomchenko et. al. (2007), Seetawan et al. (2011), Jalalah et al. (2013) reported that for $4 \mathrm{wt} \%$ silver doped $\mathrm{ZnO}$, the position of $(002)$ was shifted to lower $2 \theta\left(0.700^{\circ}\right)$ with increasing $\mathrm{Ag}$ dopant, in our case shift is small $\left(0.100^{\circ}\right)$. It is might be due to the segregation of $\mathrm{Ag}$ particles in the grain boundaries of $\mathrm{ZnO}$ crystallites rather than going into the lattice of $\mathrm{ZnO}$ or only an insufficient quantity may be going to substitution Zn site.

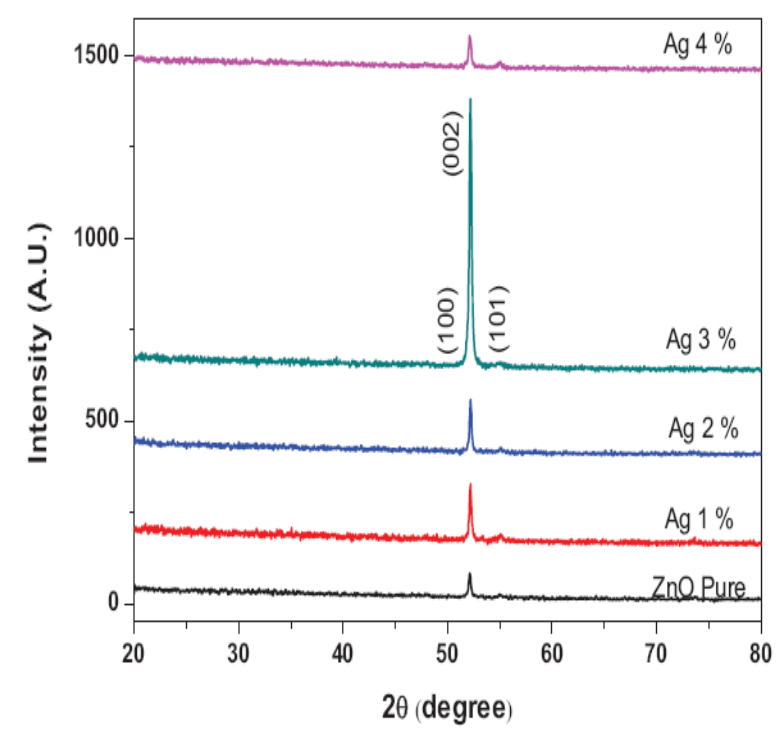

Fig. 2. XRD patterns of undoped and Ag doped $\mathrm{ZnO}$ thin films prepared by spray pyrolysis onto glass substrates.

No peaks corresponds to either Ag metal or any of its oxide were observed in the patterns, which indicates that, within the limit of $\mathrm{X}$-ray diffraction no additional phase is present in the $\mathrm{Ag}: \mathrm{ZnO}$ films.
It is evident from XRD analysis and previous reports, the $\mathrm{Ag}$ doped $\mathrm{ZnO}$ films have preferred orientation along (002) plane (Teoh et al., 2012). Because $\mathrm{Ag}+$ ions have larger ionic radius $(0.122$ $\mathrm{nm})$ than $\mathrm{Zn} 2+(0.074 \mathrm{~nm})$, they either substitute ions of $\mathrm{Zn} 2+$ leading to the distortion of unit cell or segregate at the grain boundaries of $\mathrm{ZnO}$ and hence induced considerable distortion and faster growth of $\mathrm{ZnO}$ grains (Khomchenko et al., 2007; Seetawan et al., 2011). Ag+ would preferentially choose to site in the vicinity of grain boundaries due to its larger radius (Myers et al., 2015).

The intensity of the $\mathrm{ZnO}$ (002) plane increases with Ag until 3 At $\%$ and then decreases with further increase of the Ag which suggest that $3 \mathrm{At}$ $\% \mathrm{Ag}$ doping can enhance the $\mathrm{ZnO}$ (002) preferential orientation but excess Ag doping will deteriorate it. This may be due to the fact that $3 \mathrm{At}$ $\% \mathrm{Ag}$ quantity of $\mathrm{Ag}$ atoms exists an interstitial that share the oxygen with $\mathrm{Zn}$ atoms and hence improve the $(002)$ orientation. The excess Ag doping atoms can be energetically favorable to coalesce into metallic silver cluster and hence inhibit $\mathrm{c}-$ axis prepared growth of $\mathrm{ZnO}$ film.

\section{Morphological properties}

The morphology of the $\mathrm{ZnO}$ thin films were examined by scanning electron microscopy. Figure
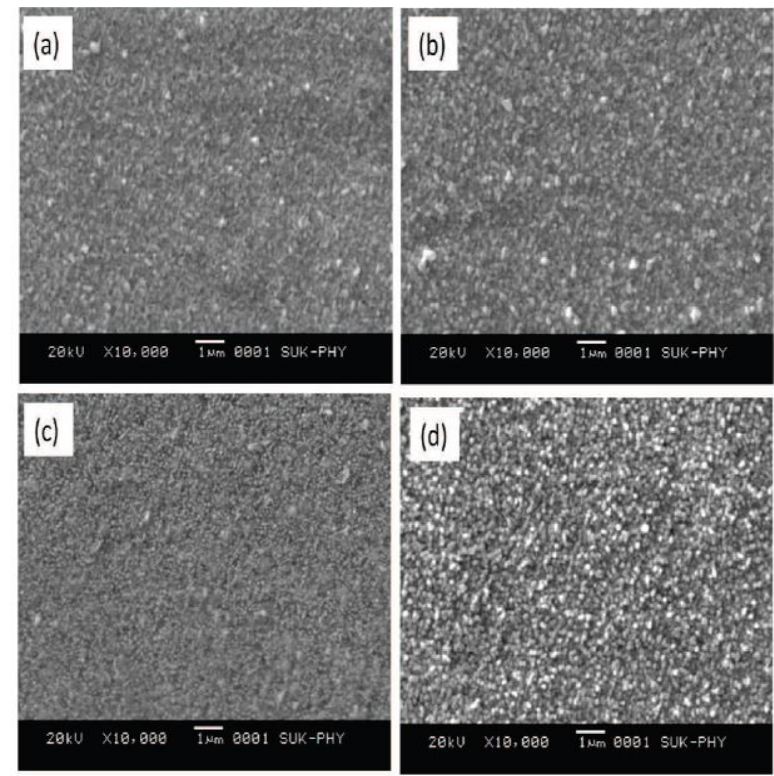

Fig. 3. Scanning Electron micrographs of (a) $\mathrm{ZnOAg}_{1}$, (b) $\mathrm{ZnOAg}_{2}$, (c) $\mathrm{ZnOAg}_{3}$, (d) $\mathrm{ZnOAg}_{4}$.

3 (a-d) shows SEM images of $1 \%-4 \%$ Ag doped $\mathrm{ZnO}$ thin films, respectively. The $3 \%$ of $\mathrm{Ag}$ doped $\mathrm{ZnO}$ thin film shows the smooth surface covered 
with grains. The improvement in the grains was observed as Ag doping percentage increases. Average grain size varies from 140 to $166 \mathrm{~nm}$ with Ag doping concentration. The surface of $3 \mathrm{At} \% \mathrm{Ag}$ doping film was found to be hydrophobic (Katoh et al., 2010; Kuang et al., 2016). The chemical composition is determined by the EDAX technique for the $\mathrm{ZnO}$ sample deposited at $3 \mathrm{At} \% \mathrm{Ag}$ doping (figure 4). The values of atomic wt $\%$ and mass $\%$ of elements are listed in table 1 . It has been observed that the atomic wt \% of Ag in the film is less than that of starting solution.

\section{OPTICAL PROPERTIES}

The optical transmittance spectra for the thin films recorded over wavelength range $300-800 \mathrm{~nm}$ at room temperature (figure 5). The sinusoidal nature of transmittance spectra is due to the light interference at the interface between the film and substrate materials. The transmittance of $\mathrm{Ag}: \mathrm{ZnO}$ films in the visible region decreases from 89 to 74 $\%$ as the $\mathrm{Ag}$ doping percentage increases. This decrease in the transmittance value of the $\mathrm{Ag}-\mathrm{ZnO}$ thin films are may be due to the grain boundary scattering. The optical band gap energy $\left(E_{g}\right)$ is an intrinsic property of the semiconductor and is estimated from optical absorption measurement. The optical band gap energy is found to be $3.24 \mathrm{eV}$ for pure $\mathrm{ZnO}$ thin films (Subedi et al., 2011; Shieh, et al., 2010; Xu, et al., 2009; Khanlary, et al., 2011), which is comparable to the band gap energy reported by Natsume et al. and for the $\mathrm{Ag}-\mathrm{ZnO}$ thin films, it is found to be in the range of $3.23 \mathrm{eV}$. With increasing silver contents, the absorption edge shifted slightly to a longer wavelength region. The band gap also narrowed with increasing $\mathrm{Ag}$ contents. Similar results are also observed by Sahu et al. (2011).

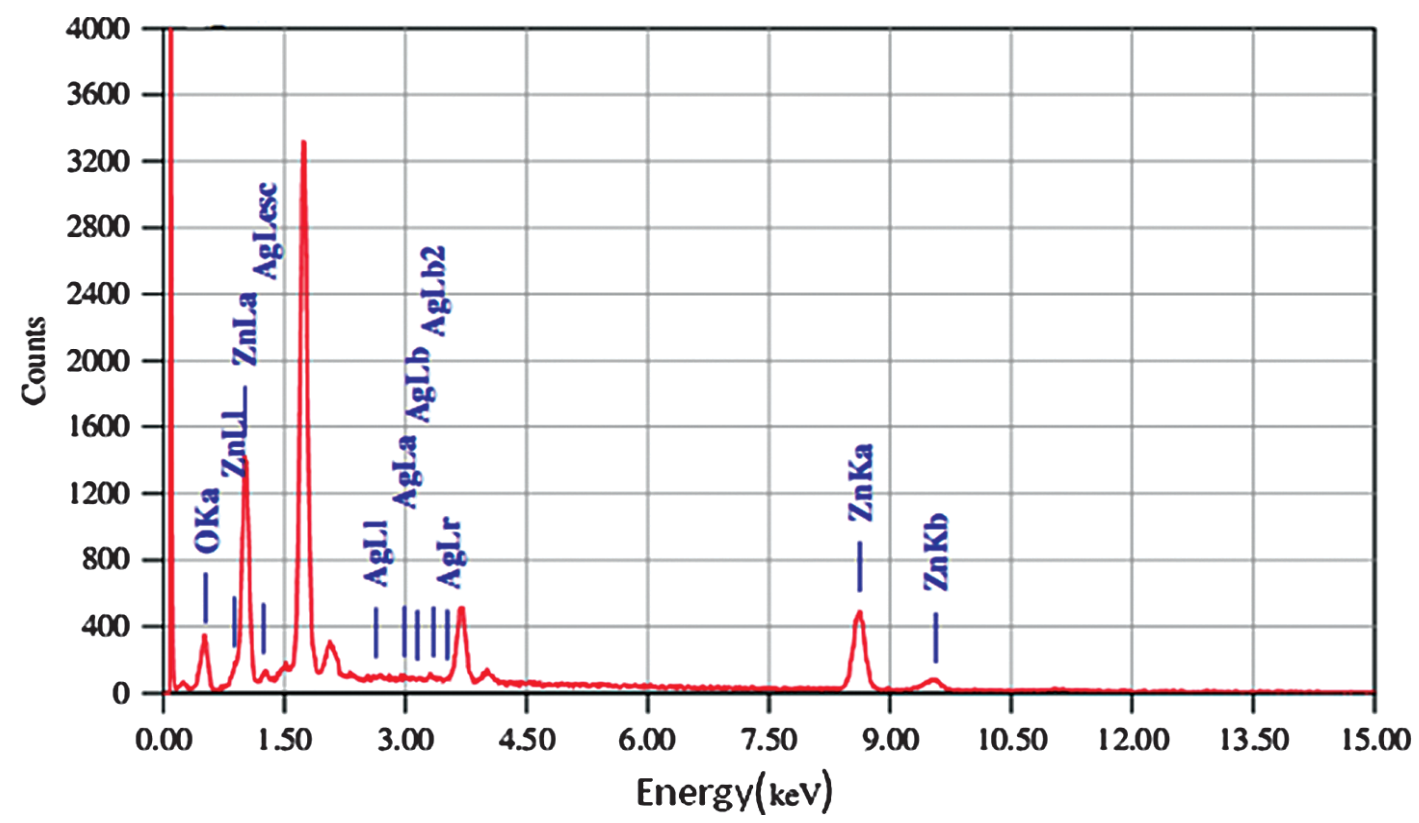

Fig. 4. EDAX pattern of typical $3 \mathrm{At} \%$ Ag doped ZnO thin film.

Table 1: EDAX data typical 3 At \% Ag doped thin films.

\begin{tabular}{|c|c|c|}
\hline Element & (Mass \%) & At \% \\
\hline OK & 16.82 & 46.09 \\
\hline Zn K & 82.27 & 53.55 \\
\hline Ag L & 0.91 & 0.36 \\
\hline Total & 100 & 100 \\
\hline
\end{tabular}




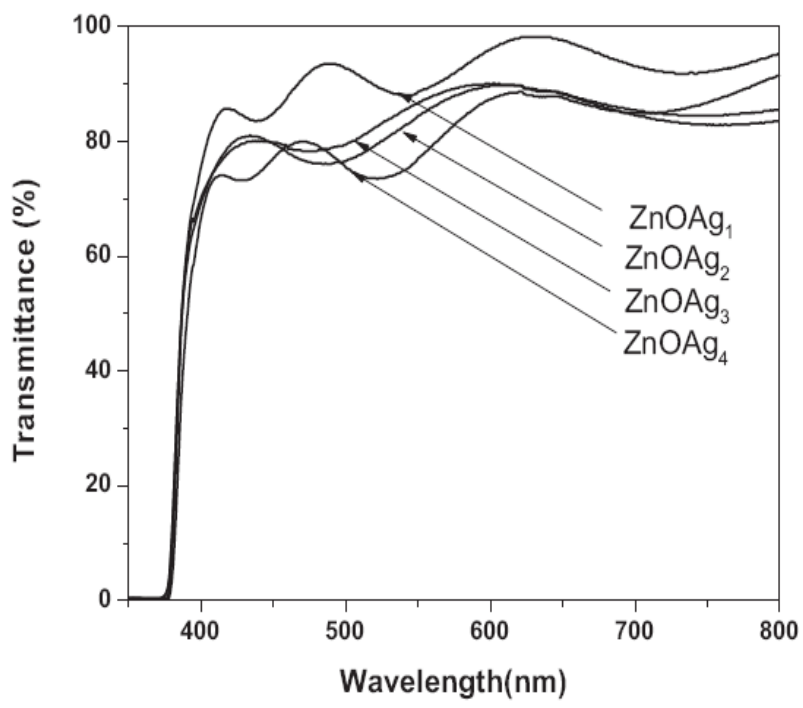

Fig. 5. Optical transmittance spectra of $\mathrm{ZnO}$ thin films deposited at various silver doping concentrations.

\section{PHOTOLUMINESCENCE PROPERTIES}

The PL spectra of undoped and $\mathrm{Ag}$ doped $\mathrm{ZnO}$ thin films were recorded at room temperature (Figure 6). Spectra reveal several bands, therefore deconvolution of the spectra was performed assuming the emission peaks to be Gaussian. The deconvoluted spectrum of typical film $\mathrm{ZnOAg}_{3}$ is shown in figure $6(\mathrm{~b})$.

The UV band related deep- level emission peak, which is observed in $\mathrm{ZnO}$ thin films. The new emission peak at about $500 \mathrm{~nm}$ is due to Ag doping. The green band in visible region is generally explained by the radiative recombination of the photogenerated holes with electrons and structural defects in crystal.

It might be due to oxygen vacancies and $\mathrm{Zn}$ interstitials (Datta et al., 2015). As Ag doping increases in $\mathrm{ZnO}$ lattice the excessive cation may generate more anion vacancies and make the concentration of the excitation increases. $\mathrm{The} \mathrm{Ag}^{+}$ ions are substituted for $\mathrm{Zn}^{2+}$ ions in the crystal, induced hybridization and charge transfer from a donar - derived impurity band to unoccupied $3 \mathrm{~d}$ states at the $\mathrm{ZnO}$ Fermi level (Holý et al., 2017). The valence of $\mathrm{Ag}$ could be assumed to be +1 or/and +2 in the Ag-doped $\mathrm{ZnO}$ films. The radius of $\mathrm{Ag}^{+}, \mathrm{Ag}^{2+}$ and $\mathrm{Zn}^{2+}$ ions are $0.089,0.072$ and 0.122 $\mathrm{nm}$, respectively. So, the $\mathrm{Ag}^{+}, \mathrm{Ag}^{2+}$ substitute $\mathrm{Zn}^{2+}$ and the $\mathrm{Ag}^{2+}$ interstitial might be the main impurity in the Ag-doped $\mathrm{ZnO}$ films. The Ag+ substitute was an accepter while the $\mathrm{Ag}^{2+}$ interstitial was a donor. When the amount of $\mathrm{Ag}$ less than $3 \mathrm{At} \%$ in the growth of Ag-doped $\mathrm{ZnO}$ films, the concentration of $\mathrm{V}_{\mathrm{Zn}}$ and $\mathrm{Z}_{\mathrm{ni}}$ might decrease, this resulted in the weakened blue band. With the increasing of $\mathrm{Ag}$ doping, the concentration of $\mathrm{Ag}^{+}$substitute and $\mathrm{Ag}^{2+}$ interstitial would increase and reach to the maximum, and then would decrease. $Z_{n i}$ might increase with the increasing of the $\mathrm{Ag}^{+}$substitute while $Z_{\mathrm{ni}}$ defects might increase with the increasing of the $\mathrm{Ag}^{2+}$ interstitial because $\mathrm{ZnO}$ was a selfassemble oxide compound. So the blue band became strong with the $\mathrm{Ag}$ increasing, and reached to the summit when Ag 3 At \%, and then decreased (Nebogatikova et al., 2015).


Fig. 6. (a) PL spectra of Ag:ZnO thin films as a function of silver doping percentage. (b) Deconvoluted spectrum of typical $\mathrm{ZnO}: \mathrm{Ag}_{3}$ film. 


\section{PHOTOELECTROCHEMICAL (PEC) CHARACTERIZATION}

Figure 7 shows variation of $I_{s c}$ and $V_{o c}$ values for different $\mathrm{Ag}$ doping concentrations. It is observed that with increasing Ag doping $I_{\mathrm{sc}}$ and $\mathrm{V}_{\mathrm{oc}}$ values increase up to 3 atomic wt \% ( At \%) Ag doping and then decrease for higher concentrations. This consists with the presence of discrete Ag clusters leading to retarded recombination of the photoinduced electron-hole pair and enhanced absorption by Surface Plasmons Resonance (SPR) phenomenon (Sutanto et al., 2015).

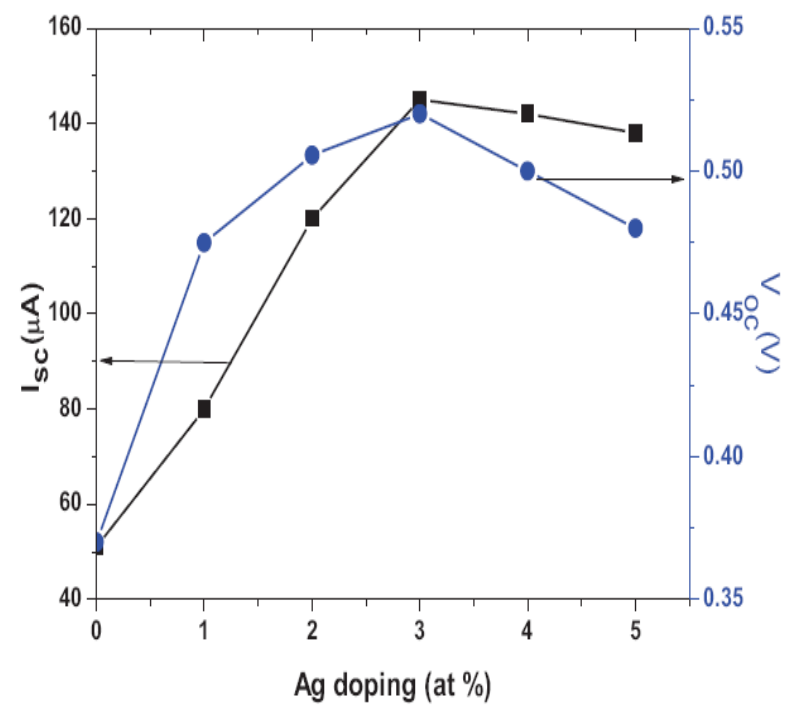

Fig. 7. Variation of $I_{s c}$ and $V_{o c}$ for the PEC cell formed with Ag:ZnO thin film versus Ag doping.

\section{PHOTOELECTROCATALYTIC DEGRADATION OF METHYLENEBLUE(MB)}

Effluents from the textile dyeing and finishing industries contain high levels of environmental contaminants, strong color, suspended solids, surfactants and some heavy metals. There are three methods for treatment of colored materials, including (1) physical methods employing precipitation, adsorption, and reverse osmosis; (2) chemical methods via oxidation (using air oxygen; ozone, $\mathrm{NaOCl}$, and $\mathrm{H}_{2} \mathrm{O}_{2}$ as oxidants) and reduction (e.g., $\mathrm{Na}_{2} \mathrm{~S}_{2} \mathrm{O}_{4}$ ); and (3) biological methods including aerobic and anaerobic treatment (Ammaih et al., 2014). The disadvantage of precipitation methods is sludge formation. The disadvantage of adsorption is that the adsorbent needs to be regularly regenerated. This is associated with additional costs and sometimes with very time-consuming procedures. Biological treatment is ineffective in cases where complicated aromatic compounds are present. Advanced oxidation processes (AOPs) provide a promising treatment option for textile wastewater compared to other treatment methods (Yan et al., 2006). The advantage of $\mathrm{R}$ : $\mathrm{ZnO} / \mathrm{UVA} \quad(\mathrm{R}=\mathrm{Ag}, \mathrm{Au})$ photoelectrocatalytic processes is that they prevent any sludge formation during the treatment process. They can be carried out at ambient conditions with the possibility of completely mineralizing organic compound to $\mathrm{CO}_{2}$. This study was undertaken to evaluate the effectiveness of the R: $\mathrm{ZnO} / \mathrm{UVA}$ ( $\mathrm{R}=$ $\mathrm{Ag}, \mathrm{Au}$ ) photoelectrocatalytic process in the decolorization of dye. Methylene blue (MB) was selected as a model dye for photocatalytic degradation using $\mathrm{R}: \mathrm{ZnO}(\mathrm{R}=\mathrm{Ag}, \mathrm{Au})$ electrodes.

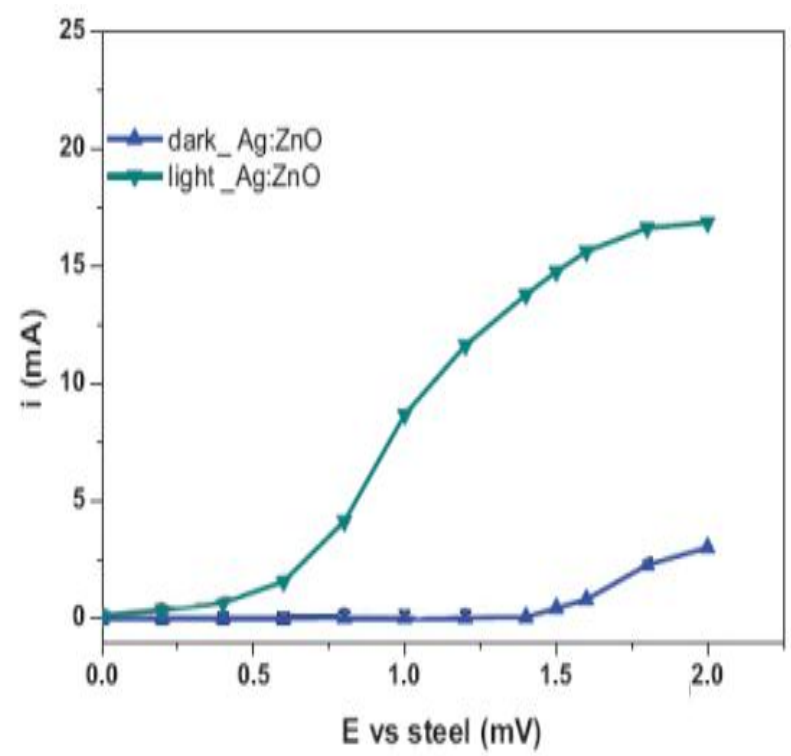

Fig. 8. Dark and light current for Ag:ZnO electrodes $\left(64 \mathrm{~cm}^{2}\right)$ under UVA illumination for $0.1 \mathrm{M} \mathrm{NaOH}$ against applied voltage with respect to steel counter with a flow rate of $12.2 \mathrm{lh}^{-1}$.

The testing of $\mathrm{Ag}: \mathrm{ZnO}$ photocatalyst has been carried out by measuring i-E curve. An i-E curve of a $64 \mathrm{~cm}^{2} \mathrm{Ag}: \mathrm{ZnO}$ catalyst in $0.1 \mathrm{M} \mathrm{NaOH}$ using a steel counter electrode at a distance of $1 \mathrm{~mm}$ under UVA illumination is shown in figure 8. The current reached to its saturation value of about $18.7 \mathrm{~mA}$ for $\mathrm{Ag}: \mathrm{ZnO}$ at bias voltage of $1.5 \mathrm{~V}$. The average photocurrent during degradation of $\mathrm{MB}$ experiment is $18 \mathrm{~mA}$ for $\mathrm{Ag}: \mathrm{ZnO}$. In last part of experiment there is slight decrease in photocurrent due to intermediates byproduct formed during photocatalytic reaction. Figure 8.1 shows extinction of $\mathrm{MB}$ with reaction time for $\mathrm{Ag}: \mathrm{ZnO}$ electrode. It 
is observed that initial degradation rate is very fast in case of $\mathrm{Ag}: \mathrm{ZnO}$ electrodes. The percentage of decolorization is calculated using formula,

Decolorization $(\%)=\frac{A-A_{0}}{A_{0}} \times 100$

Where $\mathrm{A}_{0}$ is absorbance at $\mathrm{t}=0$ and $\mathrm{A}$ is absorbance at time $\mathrm{t}$.

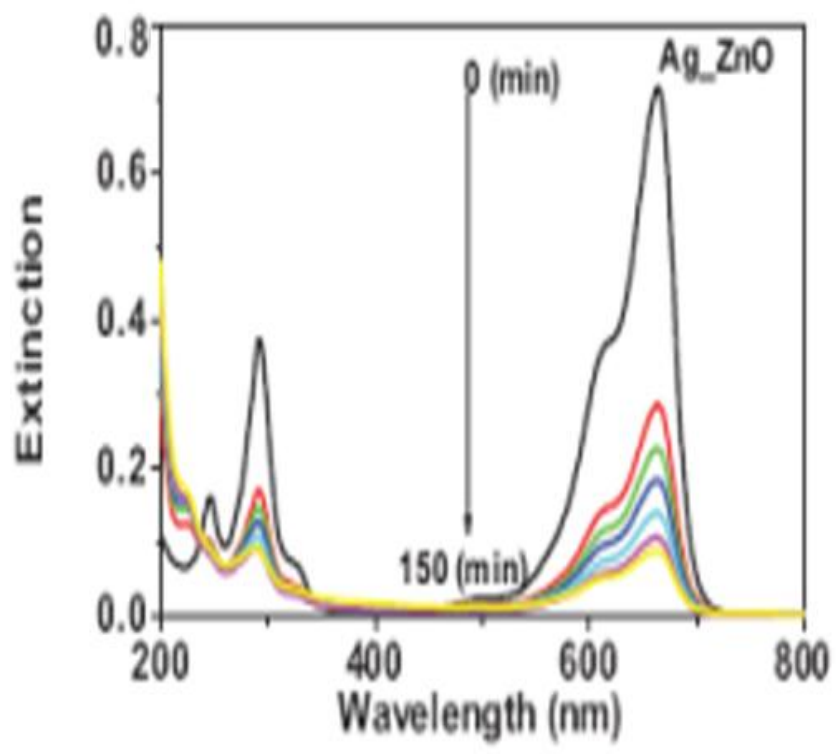

Fig. 8. Extinction spectra of MB with Ag: ZnO under UVA light illumination.

\section{CONCLUSIONS}

This paper deals with the characterization of noble metal (Ag) doped zinc oxide thin films. These films have been characterized for their PEC, structural, morphological, compositional and optical properties. The maximum value of Isc and Voc for 3 At \% $\mathrm{Ag}: \mathrm{ZnO}$ thin films confirms the optimization of doping percentage. Films are nanocrystalline and fit well with hexagonal crystal structure with no any extra phases of silver or gold or zinc compounds. For degradation of $\mathrm{MB}$ $\mathrm{Ag}: \mathrm{ZnO}$ films is Used as photoelectrode, it is observed that due to Ag: $\mathrm{ZnO} 80 \%$ degradation Of $\mathrm{MB}$ occurs in $150 \mathrm{~min}$. Photo-corrosion of $\mathrm{ZnO}$ electrode is examined by measuring zinc by atomic absorption spectroscopy and no zinc was observed in AAS measurement. The percentage of COD reduction is less than the percentage of decolorization which may be due to the formation of smaller organic compound as reduction of chemical oxygen demand reflects the extent of degradation or mineralization of organic species. Therefore, it requires more time to achieve complete mineralization of MB. From the kinetic parameters and degradation efficiency it is concluded that $\mathrm{Ag}$ : $\mathrm{ZnO}$ photocatalyst gives better performance in degradation of MB.

\section{REFERENCES}

Ammaih, Y.; Lfakir, A.; Hartiti, B.; Ridah, A.; Thevenin, P. and Siadat, M. (2014). Structural, optical and electrical properties of $\mathrm{ZnO}: \mathrm{Al}$ thin films for optoelectronic applications. Optical and Quantum Electronics, 46: 229-234.

Cho, J. S.; Baek, S. and Lee, J. C. (2011). Surface texturing of sputtered $\mathrm{ZnO}: \mathrm{Al} / \mathrm{Ag}$ back reflectors for flexible silicon thin-film solar cells. Solar Energy Material and Solar Cells, 95: 1852.

Datta, S.; Kaphle, G. C.; Baral, S. and Mookerjee, A. (2015). Study of morphology effects on magnetic interactions and band gap variations for $3 \mathrm{~d}$ late transition metal bidoped $\mathrm{ZnO}$ nanostructures by hybrid DFT calculations. The Journal of chemical physics, 143 (8): 084309.

Holý, V.; Kriegner, D.; Steiner, H.; Stangl, J.; Bauer, G. and Springholz, G. (2017). Highresolution x-ray diffraction of epitaxial bismuth chalcogenide topological insulator layers, Advances in Natural Sciences:Nanoscience and Nanotechnology, 8: 015006

Jalalah, M.; Faisal, M.; Bouzid, H.; Ismail, A. A.; Al-Sayari, S. A. (2013). Dielectric and photocatalytic properties of sulfur doped $\mathrm{TiO} 2$ nanoparticles prepared by ball milling. Materials Research Bulletin, 48: 3351-3356.

Jin, Y.; Cui, Q.; Wang, K.; Hao, J.; Wang, Q. and Zhang, J. (2011). Investigation of photoluminescence in undoped and Agdoped $\mathrm{ZnO}$ flowerlike nanocrystals. Journal of Applied Physics, 109: 053521.

Karunakaran, C.; Rajeshwari, V. and Gomathisankar, P. (2010). Antibacterial and photocatalytic activities of sonochemically prepared $\mathrm{ZnO}$ and $\mathrm{Ag}-\mathrm{ZnO}$. Journal of Alloys and Compounds, 508: 587-591.

Karunakaran, C.; Rajeswari, V. and Gomathisankar, P. (2011). Combustion synthesis of $\mathrm{ZnO}$ and $\mathrm{Ag}$-doped $\mathrm{ZnO}$ and their bactericidal and photocatalytic activities. Superlattices and Microstructures, 50: $234-241$. 
Katoh, R.; Furube, A.; Yamanaka, K.; Morikawa, T. (2010). Charge Separation and Trapping in N-Doped TiO2 Photocatalysts: A TimeResolved Microwave Conductivity Study. The Journal of Physical Chemistry Letters, 1 (22): 3261-3265

Khanlary, M. R. and Isazadeh, S. (2011). Structural and optical properties of $\mathrm{ZnO}$ thin films prepared by sol-gel method. Micro Nano Letter., 6: 767.

Khomchenko, V. S.; Kryshtab, T. G.; Savin, A. K.; Zavyalova, L. V.; Roshchina, N. N.; Rodionov, V. E. et al. (2007). Fabrication and properties of $\mathrm{ZnO}: \mathrm{Cu}$ and $\mathrm{ZnO}: \mathrm{Ag}$ thin films. Superlattices Microstruct, 42: 94.

Khomchenko, V. S.; Kushnirenko, V. I.; Papusha, V. P.; Savin, A. K. and Lytvyn, O. S. (2010). Luminescent and structural properties of ZnO-Ag films. Semiconductors, 44: 685.

Kuang, Y.; Jia, Q.; Nishiyama, H.; Yamada, T.; Kudo, A.; Domen, K. (2016). A FrontIlluminated Nanostructured Transparent $\mathrm{BiVO}_{4}$ Photoanode for $>2 \%$ Efficient Water Splitting. Advanced Energy Materials, 6: 1501645.

Lee, D. H.; Park, K. H.; Kim, S. and Lee, S. Y. (2011). Effect of $\mathrm{Ag}$ doping on the performance of $\mathrm{ZnO}$ thin film transistor. Thin Solid Films, 520: 1160-1164.

Li, W. J.; Kong, C. Y.; Ruan, H. B.; Qin, G. P.; Huang, G. J.; Yang, T. Y. et al. (2012). Electrical properties and Raman scattering investigation of $\mathrm{Ag}$ doped $\mathrm{ZnO}$ thin films. Solid State Communications, 152: 147-150.

Myers, M. A.; Khranovskyy, V.; Jian, J.; Lee, J. H.; Wang, H. and Wang, H. (2015). Photoluminescence study of p-type vs. n-type Ag-doped $\mathrm{ZnO}$ films. Journal of Applied Physics, 118: 065702.

Nebogatikova, N. A.; Antonova, I. V.; Prinz, V. Y.; Kurkina, I. I.; Vdovin, V. I.; Aleksandrov, G. N. (2015). Fluorinated graphene dielectric films obtained from functionalized graphene suspension: preparation and properties. Physical Chemistry Chemical Physics, 17: 13257.

Sahu, D.; Acharya, B. S. and Panda, A. K. (2011). Role of Ag ions on the structural evolution of nano $\mathrm{ZnO}$ clusters synthesized through ultrasonication and their optical properties. Ultrasonic Sonochemistry, 18: 601.

Seetawan, U.; Jugsujinda, S.; Seetawan, T.; Euvananont, C.; Junin, C.; Thanachayanont, C. et al. (2011). Effect of annealing temperature on the crystallography, particle size and thermopower of bulk $\mathrm{ZnO}$. Solid State Sciences, 13: 1599-1603.

Shieh, J.; Hou, F. J.; Chen, Y. C.; Chen, H. M.; Yang, S. P.; Cheng, C. C. et al. (2010). Robust air-like super hydrophobic surfaces. Advanced Materials, 22: 597-601.

Study of morphology effects on magnetic interactions and band gap variations for $3 \mathrm{~d}$ late transition metal bi-doped $\mathrm{ZnO}$ nanostructures by hybrid DFT calculations

Subedi, D. P.; Madhup, D. K.; Sharma, A.; Joshi, U. M. and Huczko, A. (2011). Study of the Wettability of $\mathrm{ZnO}$ Nanofilms. International Nano Letters, 1: 117-122.

Sutanto, H.; Nurhasanah, I. and Hidayanto, E. (2015). Deposition of $\mathrm{Ag}$ 2 6 mol\%-doped $\mathrm{ZnO}$ photocatalyst thin films by thermal spray coating method for E. coli bacteria degradation. Materials Science Forum, 827: 3-6.

Teoh, W. Y.; Scott, J. A.; Amal, R. (2012). Progress in Heterogeneous Photocatalysis: From Classical Radical Chemistry to Engineering Nanomaterials and Solar Reactors. The Journal of Physical Chemistry Letters, 3: 629-639.

Xiang, Q.; Meng, G.; Zhang, Y.; Xu, J.; Xu, P.; Pan, Q. et al. (2010). Ag nanoparticle embedded-ZnO nanorods synthesized via a photochemical method and its gas-sensing properties. Sensors Actuators B: Chemical, 2: 635-640.

$\mathrm{Xu}$, M.; Zhao, H.; Duan, M. Y. and Xu, L. X. (2009). Effect of doping with $\mathrm{Co}$ and/or $\mathrm{Cu}$ on electronic structure and optical properties of $\mathrm{ZnO}$. Journal of Applied Physics, 105: 043708.

Yan, X.; Ohno, T. K.; Nishijima, A. R.; Ohtani, B. (2006). Is methylene blue an appropriate substrate for a photocatalytic activity test? A study with visible-light responsive titania. Chemical Physics Letters, 429: 606-610. 